\title{
backstory
}

\section{Methane-munching microbes}

\author{
Nardy Kip, Julia F. van Winden, Huub J. M. Op den Camp and an array of colleagues braved hostile acidic \\ peat bogs around the world in a feat of truly collaborative research.
}

What was the objective of the work? We wanted to determine the global occurrence of methane-consuming bacteria in peat moss (Sphagnum species). Dead Sphagnum mosses decompose very slowly, turning into peat, coal and petroleum over geologic periods of time. Methane is produced during decay of the peat and can reach the atmosphere through diffusion, among other ways. However, some of this methane is consumed by methanemunching bacteria that live in symbiosis with Sphagnum mosses. The bacteria, in turn, supply the living mosses with carbon for photosynthesis. Thus, the bacteria and mosses play important roles in the carbon cycle. By assessing the occurrence of methanotrophic bacteria in peat bogs around the world, we hope to gain a better understanding of carbon recycling in peat bogs and to develop proxies that will provide palaeoecological evidence for carbon recycling.

\section{Why did you choose these particular} locations for the fieldwork?

Approximately $60 \%$ of the world's wetlands are peatland. Siberia and Canada have the most extensive bogs worldwide and were areas of particular interest. Unfortunately, it wasn't practical to visit all of these interesting locations ourselves, so we contacted people who were either doing fieldwork or living in these areas and asked them to send us the plant material. We worked together with people from many different disciplines, including geochemistry, microbiology, hydrology and ecology. We were a little jealous of the people who brought us over samples from Patagonia!

What sort of samples were you after? We wanted Sphagnum mosses and, in

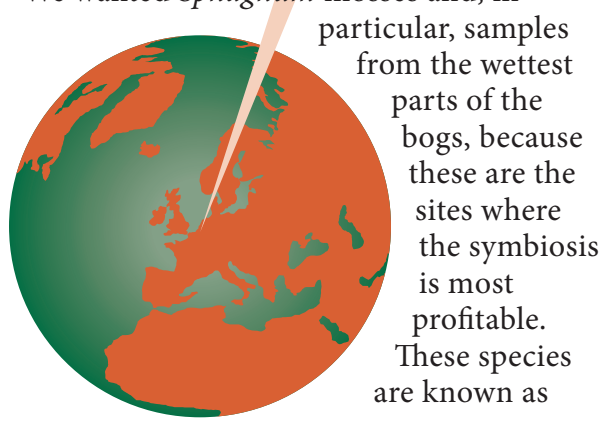

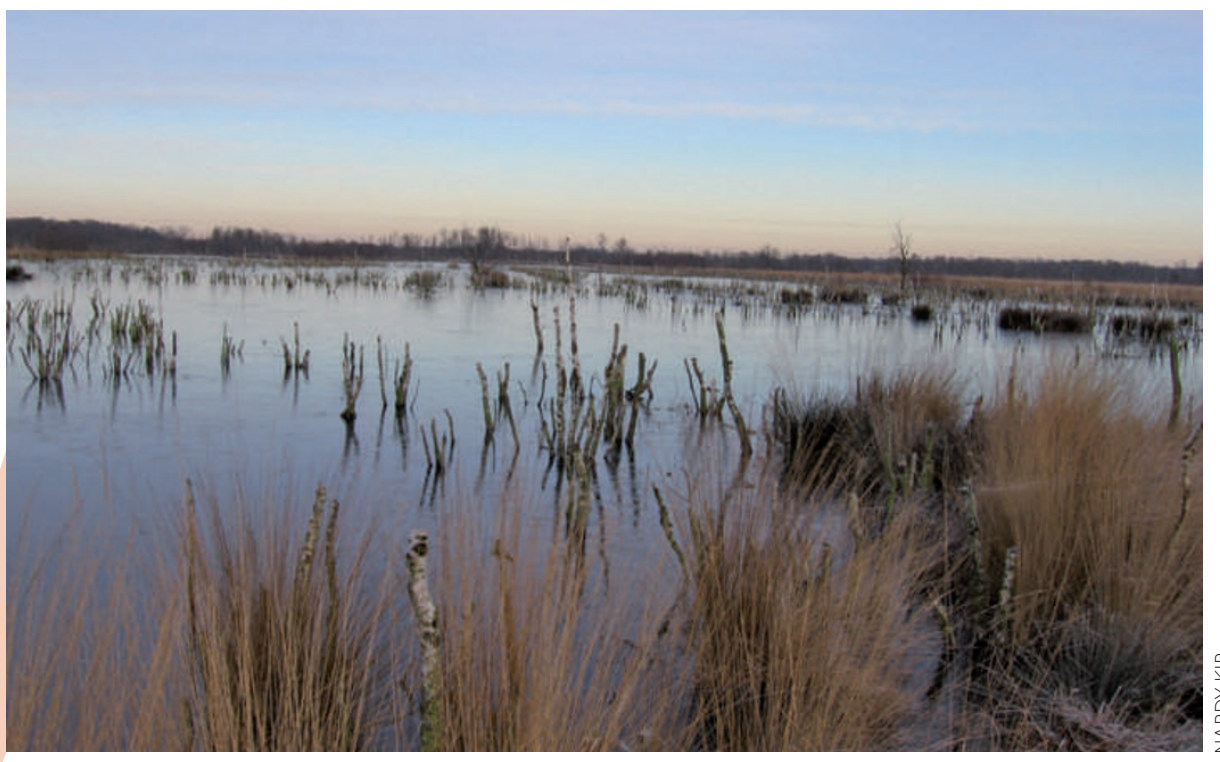

The deceptively serene, but exceptionally cold, Mariapeel peat bog in the Netherlands.

toothed sphagnum. However, we also collected other moss species from varying water levels, so that we could compare methane oxidation rates.

\section{Did you encounter any difficulties?} Regulations relating to the transport of samples varied from country to country. It was difficult to transport samples across the border from Russia, so we couldn't obtain any bog water samples from the Siberian peat bogs. And because of administration rules, we weren't able to obtain samples from New Zealand. This was unfortunate because the inclusion of these samples would have made our data set genuinely global.

\section{Did you encounter any dangerous} animals?

Acidic peat bogs are very hostile places for most creatures, so the chance of encountering dangerous animals is low. However, the mosquitoes were very annoying. One member of the crew that went to North Siberia told us that even in the tent they could still hear the buzzing of the mosquitoes nearby. They had to wear protective clothing to go outside. After hearing this, we were no longer jealous of the scientists carrying out fieldwork there.

\section{Any low points or near misses?} The bogs are generally fed by rain and form in cold temperate climates. At times we could no longer use our fingers because they were frozen. Furthermore, peat can be extremely sloppy and can suck you in as you attempt to walk through. Keeping your boots on when you try to get out is quite an achievement. It is advisable not to visit peat bogs alone - you run the risk of ending up as mummified remains.

\section{Did you learn anything new about} yourself or your team members?

We enjoyed cooperating with scientists from different disciplines and learnt a lot about the different perceptions of sampling, sample handling and analysis. For example, the size of the collected samples varied. Sample volumes collected by one crew were insufficient to perform the full analyses, whereas volumes collected by another crew were enough for hundreds of analyses. Effectively combining expertise from the fields of biology and the Earth sciences within the research discipline of biogeoscience proved to be a challenge, but we achieved truly collaborative research.

This is the Backstory to the work by Nardy Kip and colleagues, published on page 617 of this issue. 